\title{
Application of Multimedia Technology in Business English Interactive Teaching
}

\author{
Xi Wen Zhang ${ }^{1}$, Da Peng Wang ${ }^{2}$ \\ ${ }^{1}$ Foreign Languages' College, Beihua University, Jilin City, China \\ ${ }^{2}$ Financial Information Center, Jilin City, China
}

\begin{abstract}
The CALLS (Computer Assisted Language Learning System) is an effective method in business English writing teaching, particularly for students which are non-speaking countries. The CALLS is suited to self-learning because of the Rich scenario module design. Application results are examined by using the methods of group experiments, questionnaires, examinations and others. The CALLS is especially suited to creating a better studying atmosphere among students in the process of business English writing teaching than other methods.
\end{abstract}

\section{General instruction}

Business English Writing course in higher most difficult packages to considerable deliver in Business Vocational College has always been one of the English teachings. Though both teachers and students spend time and make great efforts, the results are too often far from satisfactory. In Business English Writing, many students are: 1) too often unfamiliar with the writing form of daily Business English; 2) only able to write material that baffles those who are engaged in business activities.

Many of the students who major in Business English are, unexpectedly, unable to write a resume or an application letter in English upon graduation. Such students would be defeated in the fierce job-hunting competition. In my view, this phenomenon occurs because of the defective methods and scarce knowledge involved in traditional Business English Writing teaching. With widespread application of multimedia in education, more and more educators are trying to apply modern education tools to English teaching to improve results. However, such researches often concentrate on listening, speaking and reading of Basic and College English while Business English Writing is seldom involved.

With reference to the findings of experts' research in the relevant field both at home and abroad, the writer of this paper introduces the multimedia computer into Business English Writing as an auxiliary teaching method. Application results are examined by using the methods of group experiments, questionnaires, examinations and others. Analysis of questionnaires, final examination papers and teacher-and-student forums and checks conducted by the Human Resources Departments of related enterprises show that the multimedia computer applied in Business English Writing teaching can help to remedy the deficiency of traditional teaching methods.
The computer is especially suited to creating a better studying atmosphere among students in the process of Business English Writing teaching than other methods.

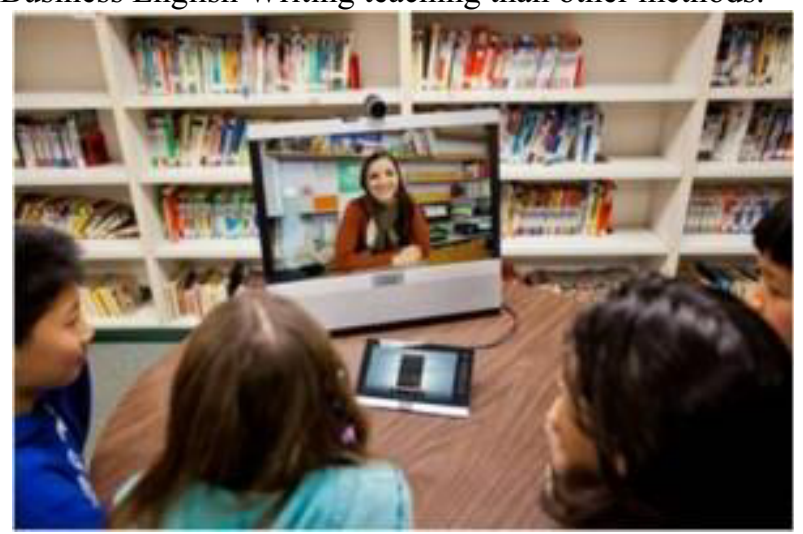

Figure 1. Interactive video transforming teaching and learning

\section{Computer-assisted language learning and effective}

With the rapid development of higher vocational education scale and continue to improve the education system and structure, there is a growing awareness of the importance of profound reform of special and vocational education in teaching and learning activities. Computerassisted language learning as a hotspot of educational reform, reform has become one of the traditional way of teaching and learning the most important factor. How to use the advanced vocational education in computerassisted language learning and effective use of a variety of modern educational technology to promote the improvement of the efficiency and effectiveness of higher vocational education has become an important issue that every vocational education teachers must concern. 
Computer Assisted Language Learning concern not only IT, but also pay attention to improving the teaching design, teaching methods, teaching resources and build teaching environment. We strive at the latest educational theory to guide, to explore business English writing in higher vocational colleges teaching how to more effectively use computer-assisted language learning design new teaching models and methods, create excellent teaching resources and the environment, hope to the majority of English teachers between vocational colleges and higher vocational computer-assisted teaching practice English Teaching Business English Writing to bridge.

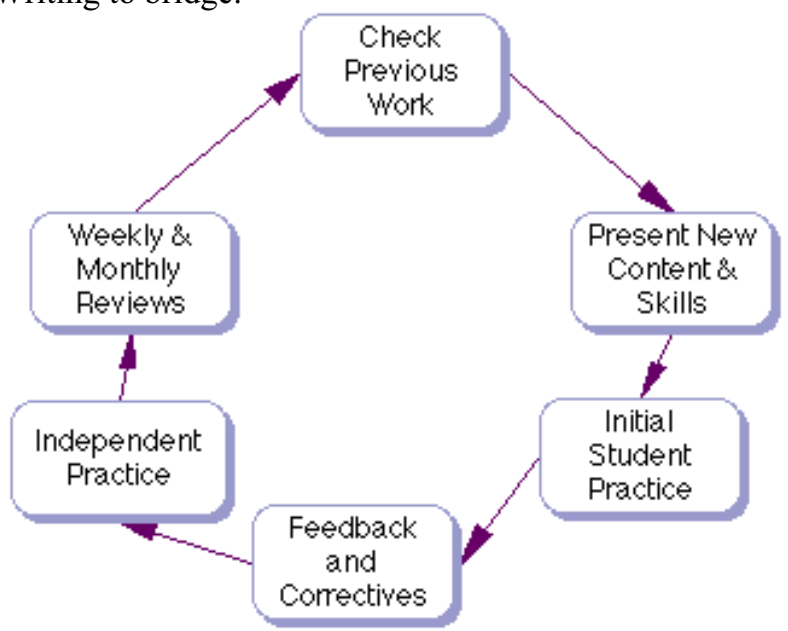

Figure 2. 3Direct-interactive teaching model

\section{Subject characteristics of business English}

Business English is the business environment in the application of English, English for Specific Purposes one belongs (ESP) of. ESP actually formed in the 1960s, but after World War II had begun germination. A time when many countries are struggling to get rid of the dilemma caused by the war, to revive the economy, the development of science and technology, to strengthen international exchanges. Because the United States at the time has a strong economic and technological strength, and is in the position of a superpower, so it uses the language - English shows its unique value in international exchanges. Many people also see that learning English learning English is no longer in order to complete a course of school education, but a way to give a job, doing business as well as the convenience of an important scientific communication tools or media. 60 years before is the English curriculum more emphasis on teaching grammar, sentence knowledge. Due to the continuous development of applied linguistics, linguists began to focus from the study of language in the form of steering the actual exchange of language law research and analysis. So people will come to realize that the same is a language, its meaning and role differences exist in different areas and situations of use. As pilot, businessman, engineer, etc., because of their profession difference, the language it uses is different. ESP is characterized emphasize teaching content rather than on teaching methods, emphasizing the teaching must meet the needs of learners and language learning practicality, as well as emphasizing the combination of vocational training and language training.

\section{Features information on teaching mode}

With the comprehensive application of information technology in the teaching field of education, profound changes in the way teaching and learning occurs. Many colleges and universities to establish a multimedia projector classroom, multimedia computer network classrooms, electronic reading room, campus paperless office platform and teaching platform and other modern teaching environment. These information technology equipment and resources must be the concept of modern education and teaching of integration, we must directly serve the Course, and penetrated into all aspects of teaching, namely improving teaching models and teaching methods in order to achieve optimal teaching effectiveness and efficiency. Meanwhile, the development and application of modern information technology for the development of new teaching model provides a unique condition.

Information on teaching models based on modern educational thought as a guide, make full use of functional advantages of modern educational technology, and give full play to the students' initiative, enthusiasm and creativity, to optimize the structure of a stable form of teaching effectiveness and efficiency of the teaching process. Typical information technology teaching mode: observable phenomena - exchange phenomena Computer Aided imagine - clear discovery - using discovery. Among them:

1. observable phenomena: the basic principles of natural phenomena in macroscopic or microscopic implied by the experimental demonstration to students, the main form of demonstration experiments for teachers, teachers focused on organizing students to observe experiments, let them discover scientific principles inherent in the experimental phenomena, and with try to resolve their existing knowledge observed.

2. AC phenomenon: Students will observe some found that to be wrong, then, to organize students to share their discoveries, by teachers and students to discuss the essence of which derives from it.

3. Computer-aided imagine: organizing students' prior knowledge combined bold imagination macroscopic or microscopic natural phenomena, and ask students to tell the reason of their own imagination, that imagination is based on scientific analysis, rather than fantasy, combined with student teachers imagine corresponding computer simulation of the phenomenon, and gradually rationalized.

4. Clearly found that: Teachers organize students to use scientific language to explain the phenomenon. 
5. The use of discovery: the practical application of organizing students to contact their findings, to solve some practical problems.

\section{Classified information teaching mode}

Various factors interact to form the teaching process of teaching mode, teaching mode information is to contact the teaching process of modern information technology environment in a number of factors each other, mutual restraint and completely constituted a stable, systematic and theorized teaching mode. Teaching modern IT environment consists of four factors: teachers, students, information technology teaching resources and information technology teaching environment. In support of information technology, the teaching can be for the individual, team and organizational forms in three classes. In the characteristics of IT application for the division basis, information can be divided into three teaching mode of teaching.

Rich source of information, knowledge, capacity, and strong interactive function, help to improve learners' learning initiative, enthusiasm, help students and higherorder thinking skills. Because of multimedia and network technology to provide user-friendly, visually interactive learning environment, capable of maps, text, sound, image and integrated multi-sensory stimulation Mao, but also by hypertext, hyperlinks, organize and manage a variety of subject knowledge teaching information, not only help to stimulate students' interest in learning and consultation sessions, collaborative learning, help students take the initiative to found the initiative to explore, acquire and maintain a situation conducive to the creation and extensive knowledge of the development of associative thinking and the establishment of the establishment of new and old knowledge contact, but also on the formation and development of students 'cognitive structure, namely, to promote students' current knowledge about the significance of the construction of the school is very favorable, but also in other instructional media or other learning environment cannot be compared.

Teaching activities, teaching methods can be more flexible, to more fully meet the learning needs of learners. With the support of multimedia and network technology, learners can study at home or in the office, you can also learn on the go, every learner in the learning process are acceptable information for their own learning abilities and learning needs.

In recent years, the use of higher vocational colleges multipurpose room and two-way control system of classroom teaching has been more widespread, multipurpose classrooms is an integrated multimedia computers, large-screen projectors, video Showcase, DVD players, video recorders and microphones and other equipment for one classroom teaching system, using the full power of teaching, computer aided teaching and demonstration tool, is currently the most popular, easy to use, the effect is the best form of teaching. This multipurpose classroom for teachers of higher vocational college's computer-aided instruction provides a good teaching environment.

Universities from the current status of view, the use of computer-aided Microsoft Office PowerPoint lectures increasingly common form of teaching that the use of electronic teaching slides complete the task of teaching in the classroom. Teachers can be prepared in advance their own good Microsoft Office PowerPoint courseware into the multi-purpose classrooms for playback. Microsoft Office PowerPoint as an intuitive and convenient multimedia authoring tool, so that front-line teaching staff can easily create their own ideas to meet the actual needs of educational software. But note that, first of all, Microsoft Office PowerPoint courseware is part or a fragment of the content of classroom teaching; it should not be the entire contents of a class.

Second, it can have voice commentary language, but do not have full voice; again, it has some interactivity, but the main function is to demonstrate; and finally, in general, it does not interact directly with students occur. These features are by such courseware position in the application of the decision; it cannot replace nor should replace the leading role of teachers in the classroom teaching. In addition, the multi-purpose classroom, teachers also can directly use CAI courseware classroom presentations. Generally, this type of CAI courseware content suitable for the performance, but it is somewhat different with Microsoft Office PowerPoint courseware, such as CAI courseware microscopic phenomena show is difficult to demonstrate by other means, the real danger of the phenomenon of the experiment, the real experiment to a very long or very short time in order to see the phenomenon, process or event in the past, we need dynamic phenomenon repeatedly observed.

\section{Virtual labs}

Virtual Lab (Virtual Laboratory) is actually a simulation using virtual reality technology or fictitious certain situations, for students to observe, manipulate and construct the objects, so that they get the experience or discoveries. In using virtual reality technology to build a variety of virtual labs, students can do all kinds of dangerous in real life, or because of space-time interval completely impossible experiments. Virtual laboratory can be immersive, by increasing the number of helmetmounted display, data gloves and the like sensing devices; it allows students to experiment with the operation in almost real virtual environment. From now, most schools usually is through the keyboard and mouse operation to perform virtual experiments, computer software can simulate a realistic three-dimensional laboratory, on the monitor students can see their operating procedures and experimental phenomena changes in real time, if the software is relatively high degree of interaction, students can operate controlled experimental details more similar to the real test, then the student to appreciate more from the experimental laws and practices. Virtual laboratory can provide students with a non-hazardous, nonexpensive way to interact with the real world. 
For my country, online education (or online teaching), after all, still a novelty, follow what educational theory, how to design and develop online courses, teaching how to implement the network, how to give the learner with the necessary assistance and guidance on how to network education (or online teaching) evaluation, etc., many questions that we should seriously think about and deal with problems. Colleges and universities on the current situation in terms of teaching, collaborative inquiry-based resource-based and collaborative inquiry process is very important, network teaching platform in which plays an extremely important role. Collaborative network teaching platform to explore is to life and life and provide a space for the exchange of teachers and students or carrier. On the network teaching platform, through which teachers can present their own point of view, through which students can present their own views; network teaching platform provides a place with a clear theme of the exchange activities for teachers and students: teachers and students can mutually ideas exchange, teachers and students can agree on a topic or task consensus learning objectives, teachers can provide active environment to students, and make or receive feedback on a topic destination; network teaching platform can enhance the interaction between teachers and students; Students must be reached through the activities of the mission objectives, teachers must provide meaningful feedback on the inherent nature of the relationship between mission objectives activities; network teaching platform can provide feedback on activities, so that students can adjust according to the feedback learning activities.

\section{Computer aided business English writing teaching model}

Teacher training and student training combined. To make better use of computer-assisted language learning, teachers and students should be short-term training, to make clear teaching objectives, basic grasp of operation of the device, effectively solve technical problems. If you do not go through the training, students spend a lot of time to figure out how to operate the device, it is a waste of limited time and anxiety, and even computer-assisted learning would be bored.

Using advanced teaching equipment and training of the students' interest combined. Regardless of any kind of teaching methods, the dominant position of the students cannot be ignored. If the student is not interested in learning, lack of motivation, it is difficult to achieve good learning outcomes. Therefore, the use of advanced teaching equipment should also pay attention to cultivate students' interest in learning.

Man-machine communication and interpersonal combined. The computer cannot replace teachers; online teaching cannot replace classroom teaching. In autonomous learning ability is not ideal situation, teachers organize the classroom is the key. The author will be introduced to computer-assisted language learning business English writing teaching, teaching effectiveness effective. But the age of vocational college students to learn basic features and it is worthy of further discussion and study. For example, in a network environment, some students keen to chat, play games, do not put effort into learning them completely. Thus, computer-assisted language learning applications to Business English Writing Course in Vocational Schools cannot be completely ignored lectures, in teaching business terms, knowledge can use traditional teaching methods, while a strong practical content can use computer-aided, two complementary kinds of teaching methods in order to better use to improve teaching effectiveness. Computerassisted language learning resources are abundant, and the prospects are bright, as an English teacher to new ideas and knowledge. Traditional teaching resources cannot meet the demands of the times. English teachers will be in the ever-changing information age, the computer-assisted language learning research and practice to new heights.

\section{References}

1. Inch Xiane Authorware interactive multimedia CAI courseware production method of Dali University 32(2007)

2. Wu Fang, HONGKONG "Business Communication" Foreign Language Teaching and Research Press, 111(2002)

3. Zhang Jianfei Development and application of "rules of the game of Table Tennis" Multimedia CAI Wuhan Institute of Physical Education Thesis, 22(2007)

4. Niehong Ling multimedia courseware evaluation to explore the basic framework of China Educational Technology Academy - Master of Education (Chemistry) Thesis, 22(2005)

5. Liu multimedia courseware development and integration of the material prepared in Kunming Metallurgy College,30(2002) 